\title{
Revitalizing International Protection: The UNHCR's Global Consultations
}

\author{
JUdith Kumin
}

\begin{abstract}
This article explains why the un High Commissioner for Refugees is convening Global Consultations on "revitalizing the international protection regime." These consultations, which will take place throughout 2001 and probably beyond, will involve state parties to the 1951 Convention relating to the Status of Refugees and its 1967 Protocol, as well as non-signatory states, non-governmental groups, academics, and practitioners of refugee law. The consultations are intended to result in a reaffirmation of the 1951 convention, and in consensus on some of the more complex interpretative aspects of that instrument. They should show the way on thorny problems faced by states in dealing with refugee and migration challenges today.
\end{abstract}

\section{Résumé}

Cet article explique pourquoi le Haut Commissariat des Nations Unies pour les réfugiés organise actuellement des Consultations globales pour "revitaliser le régime international de protection des réfugiés ». Ces consultations, qui se tiendront tout au long de l'année 2001, et probablement bien au-delà, réuniront des états signataires de la Convention de 1951 relative au statut des réfugiés et de son Protocole de 1967, ainsi que des états non-signataires, des organisations non-gouvernementales, des universitaires et des membres de la profession légale opérant dans le domaine du droit d'asile. Ces consultations ont pour but de réaffirmer la Convention de 1951 et de dégager un consensus d'opinions sur quelques-uns des aspects interprétatifs les plus complexes de cet instrument. Elles devraient indiquer la voie à suivre sur plusieurs questions épineuses auxquelles les états ont à faire face aujourd'hui lorsqu'ils confrontent les défis dans le domaine du droit d'asile et de la migration.
$\mathrm{E}$ very year in October, at the annual meeting of the UnHCR's Executive Committee, the assembled states agree to a "Conclusion on International Protection." The conclusion adopted at the fifty-first meeting of the committee in October 2000 was a departure from the usual approach. Missing from it is the lengthy enumeration of accepted principles and the appeal to states to take specific steps to improve refugee protection. Instead, in its most recent conclusion, the Executive Committee limited itself to "[Welcoming] the proposal of UNHCR to commence a process of Global Consultations with States ... to revitalize the international protection regime and to discuss measures to ensure international protection for all who need it ..."

Why is the UNHCR taking this step now? What are the goals of these Global Consultations, and what is the likely outcome? Who stands to benefit from this process-and does anyone stand to lose from it? These questions are being asked in governmental and non-governmental circles alike.

The UNHCR proposal to organize Global Consultations on the international refugee protection regime was first presented to governments in July 2000. It was motivated by a number of parallel considerations: States in all regions of the world are preoccupied by growing numbers of refugees and asylum-seekers. They are unsure how to meet the challenges posed by irregular migration and by abuse of asylum procedures. And they are frustrated by the seemingly intractable nature of certain refugee problems. States often complain that the current international legal regime is inadequate to address these problems.

At the same time, the UNHCR is noting restrictions on access to asylum, and the deteriorating quality of asylum, in many parts of the world. The agency worries that the universal refugee protection regime, which was set up in the aftermath of World War II, will become increasingly weak and fragmented. It firmly believes that a universally 
supported protection regime that is stable and predictable is in the interests of states and refugees alike.

The primary goal of the consultations is therefore to enhance refugee protection. The consultations are not intended to provide governments with a forum to "re-open" or "re-negotiate" the 1951 Convention relating to the Status of Refugees - though one or the other government may well be tempted by such a prospect. But un Secretary General Kofi Annan, addressing this year's UNHCR Executive Committee, insisted that "we must strengthen the notion of asylum - the bedrock on which all our work for refugees is based. States must resist the temptation to deal with their immigration problems, or what they perceive as such, by limiting the protection they give to refugees or by denying asylum-seekers access to their territory." Annan welcomed the UNHCR proposal to launch Global Consultations aimed at "revitalizing the protection regime" and at "reaffirming the centrality of the 1951 Convention."

It is obvious, however, that a universal refugee protection regime is useful only if it has unwavering international agreement and support, and that it can be effective only if it is responsive to the concerns of all. Not only refugees, but also their host communities, states, and the international community in general have an interest in the functioning of the refugee protection system. Balancing competing interests is a permanent feature of human rights law, and refugee law is no exception. The consultations, which will bring together not only government representatives, but also non-governmental agencies, academic experts, and practitioners of refugee law, should provide a forum for discussing the issues and reaching a proper balance.

The UNHCR has suggested that the consultations be composed of a three-fold process, organized around three very broad purposes, which can be thought of as "tracks." The first should consist of a reaffirmation of the commitment of states to the full and effective implementation of the 1951 Convention relating to the Status of Refugees and its 1967 protocol. The 1951 convention will mark its fiftieth anniversary in July 2001 - an ideal occasion for states to recommit themselves to the Magna Carta of international refugee law. It is also an occasion to appeal for more universal accession to the convention and protocol, which have 140 signatories. By comparison, 198 states (all but the United States and Somalia) have acceded to the much more recent 1989 Convention on the Rights of the Child.

The second track will be devoted to examining and seeking consensus on specific interpretative aspects of the convention. State parties as well as representatives of nongovernmental organizations and refugee law experts will meet in round-tables to explore developments and trends in law and practice relating to the convention. Topics will include the interpretation of the refugee definition (for instance, such aspects as gender-based persecution, or membership of a social group); interpretation of the convention's exclusion and cessation clauses; and the UNHCR's supervisory role, including article 35 of the convention. These are all areas where greater agreement on the interpretation of the convention would strengthen the instrument itself.

The third track is likely to be the most challenging one, since it will tackle areas of tension between migration control concerns and refugee protection. It will be devoted to issues that do not fall strictly within the confines of the 1951 convention, or are not adequately covered by the convention, but are nonetheless important to the international refugee protection regime. The UNHCR hopes that participants will map out new pathways for resolution of these problems.

Discussions within the third track will be broadened to include states that are not signatories to the 1951 convention or its 1967 protocol, along with those that are. There are many potential topics in this track: methods to maintain the civilian nature of asylum during large-scale refugee flows; how to disentangle refugees and asylum-seekers from the web of immigration control measures; and ways to strengthen the capacity of first asylum countries to offer protection, to name just a few.

These Global Consultations are not a no-risk, or even a low-risk, venture. Although during meeting after meeting of the UNHCR's Executive Committee, governments repeat that protection is the UNHCR's primary function, and although they encourage the agency to give top priority to its protection mandate, it is precisely the exercise of this responsibility that generates the most suspicion, and sometimes even hostility, among states.

The problems that challenge the delivery of protection to refugees in the twenty-first century cut across regions of the world and groups of asylum-seekers and refugees with surprising commonality. While the problems are many and complex, they can be summarized under three main headings.

The most acute question is, How can protection of refugees be ensured during a "mass influx"? In the post-cold war period, these large-scale population movements are usually the result of a new and particularly brutal type of conflict, one waged within the borders of a state, pitting groups against each other along ethnic or religious lines. The combatants show blatant disregard for human rights norms and international humanitarian law. Civilians flee, 
but often take the conflict with them. When armed elements are among the refugee groups, and/or when the conflict spills across borders, trouble is not far behind.

In these mass influxes, concerns about national security and the safety of the population in neighbouring countries often result in the closure of borders to persons in flight, the denial of asylum, the detention of refugees, and even in refoulement. It is hardly surprising that in such contexts, refugees become a convenient scapegoat for all manner of national problems, thus fuelling xenophobia and acts of hostility toward the refugees themselves. Especially where a conflict has been going on for years (or even decades) with no end to the resulting refugee problem in sight, and when international humanitarian assistance has fallen to pitifully low levels, asylum fatigue tends to translate into harsh policies toward those who are the innocent victims.

On the other side of the coin, but not altogether different, are situations where persons seeking asylum arrive not in large groups, but individually, although in large numbers, and where their eligibility for refugee protection is determined case by case. Countries are concerned about over-burdening the structures that have been established to handle such claims, about the rising costs of the system, about abuse of these procedures, and about the authorities' inability to return persons to their countries of origin, when they have been found not to be in need of protection.

The most common response in such situations has been to opt for a variety of control measures, in an effort to reduce the number of persons who are able to reach countries of potential asylum. Protection (of the state) from the pressures of irregular migration (including refugees and asylum-seekers) thus begins to take precedence over refugee protection. When this happens, refugees and asylumseekers are very often demonized. They tend to be "criminalized" in the public eye because of their illegal entry, use of false documents, or their resort to the services of people-smugglers. It is not uncommon for the media in Western countries to refer to asylum-seekers, illegal immigrants, criminals, and even to terrorists in the same breath.

Finally, both in situations of mass influx and individual arrivals, host countries are concerned about how to find solutions for those persons who are in need of protection. It is a sad fact that the much-touted and "preferred" solution of voluntary repatriation is often not achievable, because of chronic conflict or insecurity in the country of origin. In fact, where large-scale repatriation has taken place in recent years, it has frequently been under conditions that are less than satisfactory. The resettlement of refugees to third countries (primarily the United States, Canada, and
Australia) offers refugees a genuine new start, and asylum in the fullest sense of the word. But resettlement is an option for a minute proportion of the world's refugees-currently only about 100,00o places a year are available.

At the same time, the possibility for refugees to settle and become self-sufficient in their first countries of asylum is increasingly rare. Former President Julius Nyerere of Tanzania told the UNHCR in an interview just months before his death that, paradoxically, democratization may make local integration more, not less, difficult. When he was in office in the 1970s, he said, he had near absolute powers and could easily decide to give asylum to thousands of refugees. He contrasted the free hand he had at the time with the situation of the current, democratically elected president. The latter, he pointed out, has to deal with party politics, the population's xenophobic fears, and competition for scarce resources. He will inevitably have to be more cautious in publicly upholding respect for asylum.

The Global Consultations will take place throughout 2001 and are likely to continue well into 2002, with events in several regions of the world. In convening these consultations, the UNHCR recognizes that refugee protection is not a static function. To be viable, it has to be able to adjust and develop as the world changes. But this adjustment must be rooted in a solid, normative, rights-based framework. If the consultations result in a reaffirmation of that framework, and succeed in providing an impetus for workable new approaches to today's refugee protection challenges, they will have met their objective.

Judith Kumin is the representative in Canada of the United Nations High Commissioner for Refugees. 